\title{
Succession from bog pine (Pinus uncinata var. rotundata) to Norway spruce (Picea abies) stands in relation to anthropic factors in Les Saignolis bog, Jura Mountains, Switzerland
}

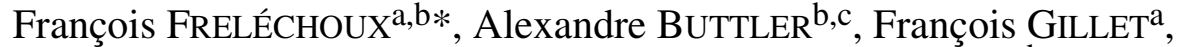 \\ Jean-Michel GoBAT ${ }^{\mathrm{a}}$ and Fritz H. SCHWEINGRUBER ${ }^{\mathrm{d}}$ \\ ${ }^{a}$ Laboratoire d'Écologie végétale et de Phytosociologie, Institut de Botanique de l'Université de Neuchâtel, \\ rue Emile-Argand 11, 2007 Neuchâtel, Switzerland \\ b WSL Antenne romande, Swiss Federal Research Institute, Case postale 96, 1015 Lausanne, Switzerland \\ ${ }^{c}$ Laboratoire de Chrono-écologie, UMR 6565 CNRS, UFR des Sciences et Techniques, 16 route de Gray, \\ Université de Franche-Comté, 25030 Besançon, France \\ d WSL Swiss Federal Research Institute, Zürcherstrasse 111, 8903 Birmensdorf, Switzerland
}

(Received 25 February 2002; accepted 23 May 2002)

\begin{abstract}
In Jura bogs, on deep and nutrient-poor peat, the ecotone between bog pine forest and Norway spruce forest is sharp and, in a few disturbed situations, no succession pine forest-spruce forest occurs. The bog Les Saignolis lies at the top of an anticline, on thin and oligotrophic peat. Several documents attest some anthropic disturbances (clear cut and drainage). Beside these historical data and with the aim of reconstructing vegetation dynamics and tree growth, we realised synusial phytosociological relevés and, in a mixed pine-spruce stand, we studied tree radial growth. Following the clear cut, the bog pine, the pubescent birch, and the Norway spruce settled simultaneously. The birch disappeared rapidly. The present cohort of pine settled and grew rapidly, and then declined because of the competition by spruce. Spruce settled progressively and increased its growth regularly except when pine settled and grew. Interspecific competition between pines and spruces and intraspecific competition between dominant and sub-dominant spruces were put into evidence by radial growth analysis.
\end{abstract}

raised bog / disturbance / succession / dendroecology / synusial phytosociology

Résumé - Succession pinède-pessière en relation avec les facteurs anthropiques dans la tourbière des Saignolis, chaîne jurassienne, Suisse. Dans les hauts marais jurassiens, sur tourbe épaisse et oligotrophe, la limite entre la pinède et la ceinture d'épicéas est très nette et il n'y a pas de succession pinède-pessière en situations peu perturbées. Le marais des Saignolis est situé au sommet d'un anticlinal, sur tourbe mince et oligotrophe. Plusieurs documents témoignent de perturbations anthropiques (coupe rase et drainage). En complément aux données historiques et dans le but de reconstruire la dynamique de la végétation et de la croissance des arbres, nous avons effectué des relevés phytosociologiques synusiaux et, dans un peuplement mixte pin-épicéa, nous avons étudié la croissance radiale des arbres. Après l'éclaircie, le pin, le bouleau pubescent et l'épicéa se sont installés simultanément. Le bouleau a rapidement disparu. La cohorte actuelle du pin s'est installée et a grandi rapidement, puis a dépéri, concurrencée par l'épicéa. L'épicéa s'est installé progressivement et a régulièrement augmenté sa croissance, sauf au moment de l'installation et de la croissance des pins. La compétition interspécifique entre pins et épicéas et la compétition intraspécifique entre épicéas dominants et sub-dominants ont été mises en évidence par l'analyse de la croissance radiale.

haut marais / perturbation / succession / dendroécologie / phytosociologie synusiale

\section{INTRODUCTION}

Raised bogs in the Jura Mountains are small, most of them less than 20 ha, which is typical in this karst environment where impermeable substrates condition their geographical location. Most of them were drained and exploited for peat between the 18th and the 20th century. The drying up which followed these disturbances has increased tree encroachment.
The three tree species which spread most are pubescent birch (Betula pubescens), bog pine (Pinus uncinata var. rotundata), and Norway spruce (Picea abies). Based on a large survey in the Jura Mountains, several woodland vegetation units with these three species have been described [16].

Four pinewood types have been described in drained but uncut situations on oligotrophic deep peat, following a concentric distribution in relation to depth to water level in 
every single bog [18]. Bog-pine's stand structure (e.g. age, height, and growth) is type-specific and depends on historical and anthropic factors like peat exploitation and drainage [17]. Birch forests are mainly found in cut over bogs and in minerotrophic situations. Spruce forests are found at the natural edge of raised bogs, on shallow peaty and rather minerotrophic soils, sometimes on cut surfaces [16] where they can form mixed stands [6].

If pine species are generally considered pioneers, they are also relegated by competition to extreme habitats hostile to other trees [43]. In the Jura Mountains, there are two ecotypes of Pinus uncinata var. rotundata, one living on top of calcareous cliffs, the other one living in raised bogs [46]. The latter, the bog pine, withstands very cold climate, high water table and nutrient-poor habitat. Norway spruce has a larger ecological range in this area and can be found in several forest types [44] or in wooded pastures [19]. It can act as well as a pioneer species [38], as a post-pioneer or a late successional one [42]. Contrary to pine, spruce seeds can germinate as well in full light as in the shadow. When they develop in raised bogs, spruces may become chlorotic when the water table is too high and when there is a lack of minerals.

While Guinochet [26] suggested a possible primary succession from bog pine to spruce woodlands, other authors $[44,15]$ disagreed with this point of view. According to Richard [44], such an evolution may occur, but only after human disturbances. In most of the prospected sites of the Jura range, the limit between the central pine forest and the spruce belt was sharp [16] and no succession pine-spruce occurred.

Historical data report that there was a clear cut on the bog and in the vicinity at the beginning of the 19th century [28]. At this time, the secondary succession hosted co-dominant populations of pubescent birch, bog pine and spruce. Vegetation maps after Favre and Thiébaud [14], Richard [45] and Bartolomé [2] indicate the decline of the pine woodland surface in the middle of the bog and the concomitant centripetal spreading of the spruce woodland (see Fig. 1).

In this paper our objectives are: (i) to give a description of the vegetation of pine forest and mixed pine-spruce forest based on synusial phytosociology; (ii) to show, based on tree ring sequences, the tree colonization, the apical and radial growth, the height and age structure, and the intra- and interspecific competition of bog pine and Norway spruce in the mixed stand; (iii) to propose a dynamic scheme (spatiotemporal reconstruction) based on historical data, synchronical synusial observations of the vegetation and diachronic observations based on tree radial growth.

\section{MATERIALS AND METHODS}

\subsection{Study site}

While most of raised bog of the Jura are situated in syncline and consist of peat of several meters depth, the bog of le Saignolis lies on top of an anticline, on an impermeable clayey substrate named "Furcil's marl layer" [14], at an altitude of $1257 \mathrm{~m}$ a.s.l. The peat is shallow ( $<1 \mathrm{~m}$ depth) but nevertheless acidic ( $\mathrm{pH}$ values around 4$)$ and nutrient-poor [2]. In the studied area, the bog was drained but never exploited for peat. Trees were cut around 1800 [28]. a
1907

C
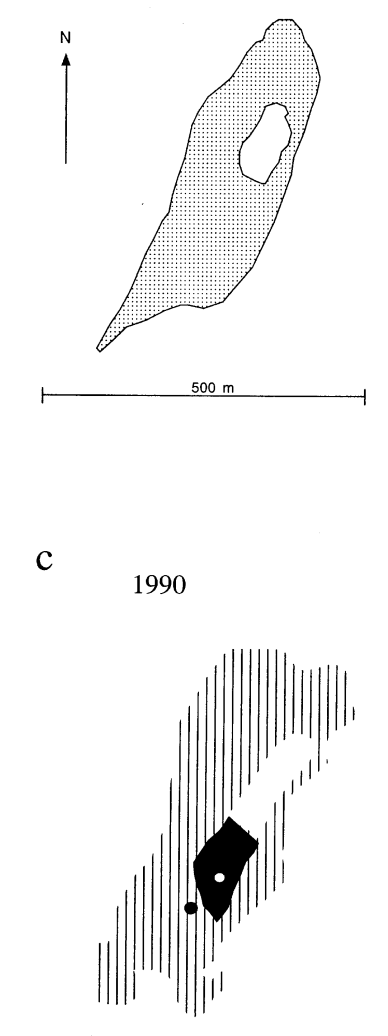

b

1965

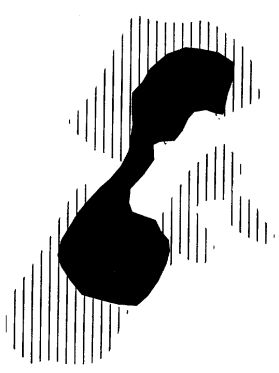

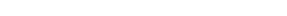

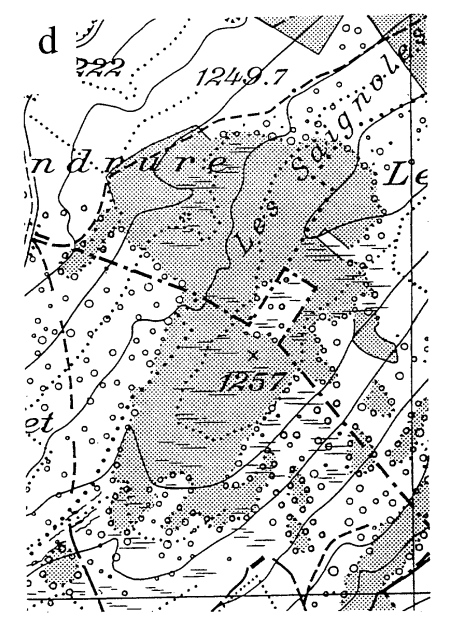

Figure 1. Successive vegetation maps from the raised bog Les Saignolis adapted from: (a) Favre and Thiébaud [14], (b) Richard [45] and (c) Bartolomé [2], showing the decline of the pine woodland area in the middle of the bog and the concomitant centripetal spreading of the spruce woodland. The topographical fund (reproduced with permission of the Swiss Federal Office of Topography, BA0113893) is given in (d). Dotted hatches: bog pine, pubescent birch and Norway mixed woodland; vertical hatches: spruce woodland; black areas: pine woodland; white circle: phytocoenosis No 1 (pine stand); black circle: phytocoenosis No 2 (bog pine and Norway spruce mixed stand).

In the Jura Mountains, the climate is under the double influence of humid winds from the Atlantic (westerly) and of continental anticyclones (originating in the east). In the highest part of the range, mean annual precipitation is about $1500 \mathrm{~mm}$ with a peak in summer. Mean annual temperature in bogs is about $5{ }^{\circ} \mathrm{C}$; the mean of the coldest month (January) is ca. $-4^{\circ} \mathrm{C}$, and the mean of the warmest month (July) is ca. $13{ }^{\circ} \mathrm{C}$ [16]. The snow period extends from November to April and the mean of snow height from the last 71 years (daily values from December 1 to March 31 only, in the nearest meteorological station of La Chaux-de-Fonds) is $23.1 \mathrm{~cm}$ (range: 2.6-100.9 cm; median of monthly means: $17.2 \mathrm{~cm}$ ) [1].

\subsection{Vegetation}

Integrated synusial phytosociology has been used to describe vegetation patterns [18]. Based on the sigmatist method of 
Braun-Blanquet [7], this method [20, 21] aims at describing complex vegetation structures and also at emphasising the dynamic links between their constituent elements. Two spatio-temporal organisation levels have been used for the description of the vegetation: the synusia (elementary one-layered concrete vegetation unit directly linked to uniform environmental conditions as microclimate, microtopography, soil, biotic factors) and the phytocoenosis (complex of synusiae functionally strongly linked both in space and in time). We did two phytocoenotic relevés (Fig. 1) within areas containing all synusiae of each respective phytocenosis, the first (No 1) in the central part of the bog, where bog pine dominated vegetation occurred (coord. $47^{\circ} 5^{\prime} 21^{\prime}, \mathrm{N} ; 6^{\circ} 45^{\prime} 53^{\prime}$ ' E; surface: $450 \mathrm{~m}^{2}$ ), and the second (No 2) in the pine and spruce mixed stand (coord. $47^{\circ} 5^{\prime} 17^{\prime}$ ' N; $6^{\circ} 45^{\prime} 50$ ' E; surface: $900 \mathrm{~m}^{2}$ ). Surfaces of synusiae ranged from some $\mathrm{dm}^{2}$ (scarcer moss synusiae) to the whole surface of the phytocenosis (e.g. tree synusiae). Phytocoenotic relevés and their constituent synusial relevés have been analysed together with others to achieve the general typology of woodland communities in raised bogs [16]. This data-base comprised 94 phytocoenotic relevés and 767 synusial relevés of bog woodland communities of the Jura Mountains. Numerical analysis and subsequent classification of the synusial relevés allowed to recognize the elementary syntaxa, indicated in this work by their codes (e.g. M312, H201, etc.). For both phytocoenoses, we did (i) a field drawing representing the location of each synusia, (ii) a dynamic diagram which summarises all spatial relationships between synusiae and hypothetical changes with time and (iii) a generalised qualitative dynamic model which aims at providing hypotheses on the vegetation dynamics based not only on vegetation description, but also on tree growth and historical data.

The nomenclature of vascular plants follows Tutin et al. [50], the one of liverworts Grolle [24], and the one of other bryophytes Corley et al. [9].

\subsection{Tree stand structure}

On a surface of $400 \mathrm{~m}^{2}$ of the bog pine and Norway spruce mixed stand (phytocoenosis No 2), all living and dead trees, apart from the scarce youngest saplings ( $<4$ years old), were counted, mapped and their main morphological characteristics measured. Height was measured directly with a folding pocket rule for the small trees, or with a clinometer for taller individuals. Diameter and basal area were calculated from the circumference at the stem base. The taller trees with diameter $>10 \mathrm{~cm}$, belonging to the canopy and the sub-canopy, were cored as low at possible, usually between 15 and $40 \mathrm{~cm}$ above the ground, with an increment core borer (one or two cores were taken), whereas smaller trees and saplings were cut and sliced at their root collar. This material was prepared in the laboratory to obtain information on the age of each tree and to allow radial growth analysis. When the pith was missing in bored cores, age read at coring height was corrected. The distance from the last visible ring to the virtual pith was based on the arc made by the last visible ring. Age correction was obtained by dividing the distance to virtual pith by the mean width of the last visible rings (mainly $5 \geq n \geq 10$ ). Mean annual apical growth of each tree was calculated as the ratio between corrected height (tree height minus coring height) and age or corrected age. The ratio between the number of trees with age correction at coring height and the total number of living trees was 93\% for pines and 51\% for spruces. On the whole, the ratio between the number of rings added and the total number of tree rings read for age estimation was only $4.2 \%$ for pines and $6.8 \%$ for spruces. Age underestimation due to coring above collar was assessed for each tree by dividing coring height by mean apical annual growth. For living spruces, mean apical annual growth was calculated for two height subgroups, respectively the shrub (undergrowth, $<8 \mathrm{~m}$ ) and the tree layer (dominant and subdominant trees, $>8 \mathrm{~m}$ ).

\subsection{Tree radial growth}

The visual method for ring-width analysis of the skeleton plot was first developed by Douglass [12] to allow cross-dating between different radii and recognition of anomalies such as missing or false rings. It was used later by Stokes and Smiley [49] and Schweingruber et al. [48] for ecological analysis. Additionally, this method allows the recognition of characteristic rings (e.g. event years based on abrupt growth changes) and characteristic years (pointer years), which represent the reaction of a whole stand, by using means of abrupt growth changes [48, 52]. It is also useful to determine tree age structure and radial growth patterns, which can be interpreted in relation to disturbances [35].

We used the skeleton plot method for the following reasons:

1. Although trees are not very sensitive in bogs, ring sequences have shown good signatures, e.g. tree ring width or latewood width event years, which permitted a good cross-dating among bog pines or among Norway spruces;

2. Increase or decrease event years based on abrupt growth changes were used as high frequency signals which are interpreted in relation to climate, to human disturbances like drainages and peat cuttings [17], to unfavourable hydrologic conditions [16] or to reconstruct the past of bog sites (this issue);

3. Abrupt growth change curves maximise medium-term fluctuations, high frequency signals being suppressed. These measurements are essential for the reconstruction of bog dynamics, which would be more difficult to demonstrate on measured, continuous ring-width sequences.

Visual readings were carried out using a stereomicroscope equipped with a micrometric eyepiece $(0.05 \mathrm{~mm}$ graduations). Data handling, calculations and graphical display followed Weber [51].

The construction of the radial growth curve of each tree is based on Abrupt Growth Changes (AGC), which can be recognised and quantified by successively comparing all the ring widths using the largest ring as a reference in each radius [48]. For each species and each year, the mean abrupt growth change curve (AGCm) was calculated by using, for all the corresponding years, the abrupt growth change information obtained for the different trees within the plot. Further details about this method are available in Freléchoux et al. [17].

\section{RESULTS}

\subsection{Vegetation}

The bog pine forest of phytocoenosis No 1 is well characterised by a hydrophilous and acidophilous vegetation of hollows and wet lawns (Figs. 2 and 3, Tab. I and Appendix). Sphagnum cuspidatum, S. papillosum, S. rubellum, S. fuscum, Drosera rotundifolia, and Carex pauciflora are among the most characteristic species of moss (M312, M306) and herb synusiae (H201) and occur mainly where the tree canopy is scarce. Near larger trees, often grouped in bunches, dryer lawns and hummocks are occurring, the shrub layer becomes denser and the spruce saplings are numerous (H205), suggesting a slow colonization by spruces. Vaccinium myrtillus is the most covering species and some spruce forest species grow under its canopy such as Vaccinium vitis-idaea, Listera cordata, Sorbus aucuparia (H205), and mosses such as Sphagnum girgensohnii (M304) or Rhytidiadelphus loreus (M327).

The spruce and bog pine mixed stand of phytocoenosis No 2 shows a simpler vegetation structure (Figs. 4 and 5, 

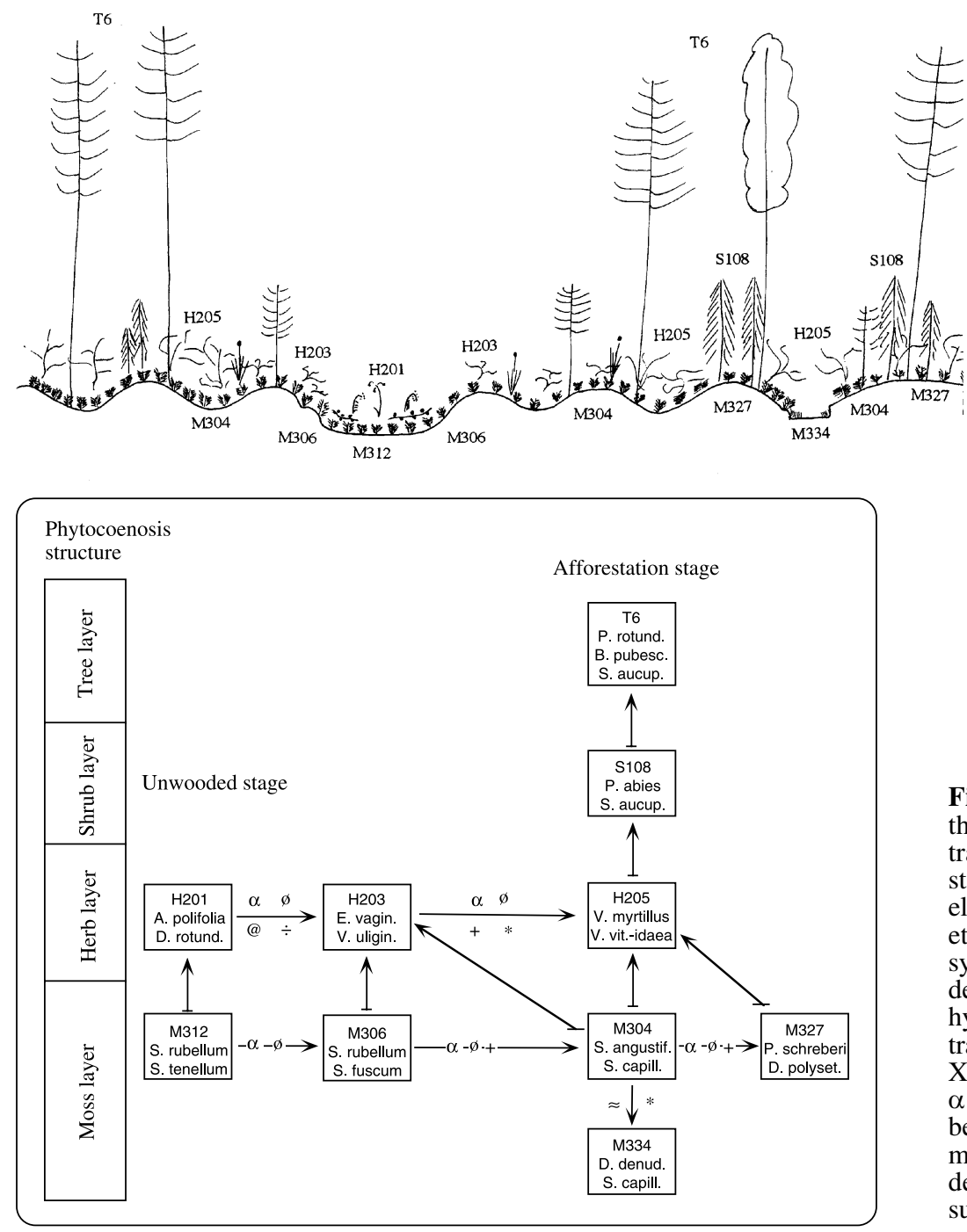

Figure 2. Sketch of the spatial pattern of the different synusiae in the bog pine stand of phytocoenosis No 1. See also the dynamic diagram in Figure 3, the synusial relevés in Table I, and the short description of elementary syntaxa in the appendix.
Tab. I and Appendix). Synusiae are less numerous and Norway spruces occupy all layers in the phytocoenosis. The bog pines, less numerous and dominated by spruces, are suppressed and many are dead. The typical vegetation of hollows and wet lawns of open pine woodland is absent. The synusia with Dicranum polysetum and Ptilium cristacastrensis (M327), the synusia with Sphagnum capillifolium, S. angustifolium and S. magellanicum (M304), and the synusia with Vaccinium vitis-idaea, V. myrtillus and Listera cordata (H206) reveal the resemblance with tall pine phytocoenosis as described in Freléchoux et al. [18].

\subsection{Tree stand structure}

In the Norway spruce and bog pine mixed stand of phytocoenosis No 2, the tree layer covers $75 \%$ of the plot surface (Tab. I, caption). The taller spruces overtop the taller pines (Tab. I, Fig. 6). Density of living spruces is higher than that of living pines (Tab. II), which are not able to regenerate in highly shaded undergrowth (Fig. 6). In contrast, the basal area of both species, considering living and dead individuals, is very similar (Tab. II). The dead pines (42\% of all pines), most pollard, are found in the sub-dominant synusia (T4) whereas the dead spruces (15\% of all spruces) are occupying the undergrowth synusia (S105) (Figs. 4 and 5, Tab. II).

Living tree age-height relation (Fig. 6) shows a very different pattern for the two species. Spruces are uneven-aged and occupy several vegetation layers and synusiae. Individuals ranging from 75 to 200 years old are present in synusiae of the canopy (T3), of the sub-canopy (T4) and of the undergrowth (S105). Spruce colonization is continuous in time. The pines belong to an even-aged stand. No successful regeneration of this species has occurred for about 100 years.

The mean annual apical growth (Tab. II) reaches $14.5 \mathrm{~cm} \mathrm{yr}^{-1}$ for the pines $(n=15), 11.7 \mathrm{~cm} \mathrm{yr}^{-1}$ for the spruces $(n=20)$ in the canopy $(>8 \mathrm{~m})$ and only $3.1 \mathrm{~cm} \mathrm{yr}^{-1}$ for suppressed spruces $(n=47)$ in the undergrowth $(<8 \mathrm{~m})$, indicating that the latter are strongly suppressed. 
Table I. Vegetation tabular of the phytocoenotic relevés and their synusial relevés in the bog pine stand of phytocoenosis No 1 and in the bog pine and Norway spruce mixed stand of phytocoenosis No 2. Abundance-dominance and aggregation values according to Braun-Blanquet scale are indicated for each syntaxon and each species. Synusial relevés were attributed each to an elementary syntaxon according to the analysis of data of a more general survey [16]. Vegetation cover of layers is in phytocoenosis No 1: trees (20\%), shrubs (15\%), herbs (90\%) and mosses (80\%); in phytocoenosis No 2: trees (75\%), shrubs (20\%), herbs (60\%) and mosses (85\%).

\begin{tabular}{|c|c|c|c|c|c|c|c|c|}
\hline \multirow{2}{*}{ Tree layer: } & \multicolumn{4}{|c|}{ Phytocenosis No 1} & & \multicolumn{2}{|c|}{ Phytocenosis No 2} & \\
\hline & & & & & & & & \\
\hline Elementary syntaxon code & T6 & & & & & T3 & T4 & \\
\hline Cover-abund. aggreg. index & 2.4 & & & & & 1.2 & 4.4 & \\
\hline Betula pubescens & 2.2 & & & & & . & & \\
\hline Pinus rotundata & 5.4 & & & & & & 3.3 & \\
\hline Picea abies & 1.1 & & & & & 5.2 & 5.4 & \\
\hline Abies alba & & & & & & . & + & \\
\hline Sorbus aисираria & 1.1 & & & & & . & . & \\
\hline Shrub layer: & & & & & & & & \\
\hline Elementary syntaxon code & S108 & & & & & S105 & & \\
\hline Cover-abund. aggreg. index & 2.2 & & & & & 2.3 & & \\
\hline Betula pubescens & 2.3 & & & & & + & & \\
\hline Pinus rotundata & 3.2 & & & & & & & \\
\hline Picea abies & 3.3 & & & & & 5.3 & & \\
\hline Sorbus aucuparia & 2.2 & & & & & + & & \\
\hline Herb layer: & & & & & & & & \\
\hline Elementary syntaxon code & $\mathrm{H} 201$ & $\mathrm{H} 203$ & $\mathrm{H} 205$ & & & H206 & & \\
\hline Cover-abund. aggreg. index & 1.4 & 2.4 & 4.4 & & & 4.4 & & \\
\hline Carex nigra & 2.3 & + & + & & & . & & \\
\hline Carex echinata & 1.2 & . & . & & & . & & \\
\hline Eriophorum angustifolium & 1.1 & . & . & & & . & & \\
\hline Drosera rotundifolia & 2.2 & 2.2 & . & & & . & & \\
\hline Carex pauciflora & 2.2 & 1.2 & & & & & & \\
\hline Eriophorum vaginatum & + & 2.3 & 2.2 & & & 1.2 & & \\
\hline Vaccinium oxycoccos & 1.2 & 1.2 & & & & . & & \\
\hline Vaccinium uliginosum & 1.2 & 3.3 & 1.3 & & & 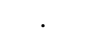 & & \\
\hline Calluna vulgaris & . & 2.2 & + & & & & & \\
\hline Vaccinium myrtillus & . & 2.3 & 4.4 & & & 3.4 & & \\
\hline Listera cordata & . & . & 2.2 & & & 1.2 & & \\
\hline Vaccinium vitis-idaea & . & 1.2 & 3.2 & & & 3.3 & & \\
\hline Melampyrum pratense & . & 2.1 & 1.2 & & & . & & \\
\hline Equisetum sylvaticum & . & . & 1.2 & & & . & & \\
\hline Tree seedlings: & & & & & & & & \\
\hline Betula pubescens & . & . & + & & & . & & \\
\hline Pinus rotundata & + & . & & & & & & \\
\hline Picea abies & . & . & 2.2 & & & 2.1 & & \\
\hline Sorbus aucuparia & . & . & 1.3 & & & . & & \\
\hline Abies alba & . & . & + & & & + & & \\
\hline Moss layer: & & & & & & & & \\
\hline Elementary syntaxon code & M312 & M306 & M304 & M327 & M334 & M304 & M327 & M334 \\
\hline Cover-abund. aggreg. index & 1.4 & 3.4 & 3.3 & 2.3 & 1.2 & 4.4 & 2.3 & 1.2 \\
\hline Sphagnum cuspidatum & 3.4 & . & $\cdot$ & $\cdot$ & $\cdot$ & $\cdot$ & 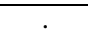 & $\cdot$ \\
\hline Sphagnum papillosum & 2.3 & . & . & . & . & . & . & . \\
\hline Calypogeia sphagnicola & + & . & . & . & . & . & . & . \\
\hline Sphagnum angustifolium & & 1.3 & + & . & . & . & & . \\
\hline Sphagnum rubellum & 1.2 & 2.2 & . & . & . & . & . & . \\
\hline Aulacomnium palustre & 1.2 & 2.2 & . & . & . & + & . & . \\
\hline Sphagnum fuscum & . & 2.3 & & . & 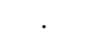 & & . & . \\
\hline Sphagnum magellanicum & 2.3 & 2.4 & 3.3 & . & 1.2 & 2.4 & . & . \\
\hline Dicranum affine & . & + & & . & & & . & . \\
\hline Sphagnum capillifolium & . & . & 3.4 & . & 1.2 & 2.4 & & 2.3 \\
\hline Sphagnum girgensohnii & & & 2.3 & & . & 1.3 & & . \\
\hline Polytrichum strictum & 1.1 & 2.2 & 2.2 & 2.2 & . & 2.2 & & . \\
\hline Pleurozium schreberi & . & 1.2 & & 3.4 & . & & 3.3 & . \\
\hline Dicranum polysetum & . & . & . & 2.3 & . & 2.3 & 2.3 & + \\
\hline Dicranum scoparium & . & . & . & 1.2 & . & & 2.2 & . \\
\hline Hylocomium splendens & . & . & . & 2.3 & . & 2.2 & 2.2 & . \\
\hline Leucobryum glaucum & . & . & . & + & . & . & & 2.4 \\
\hline Polytrichum commune & . & . & . & 1.3 & 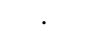 & . & & . \\
\hline Ptilium crista-castrensis & . & . & . & + & . & & 1.2 & . \\
\hline Rhytidiadelphus loreus & . & . & . & 2.3 & 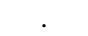 & 2.3 & 2.3 & . \\
\hline Dicranodontium denudatum & . & . & . & . & 5.5 & . & 1.2 & 4.4 \\
\hline
\end{tabular}




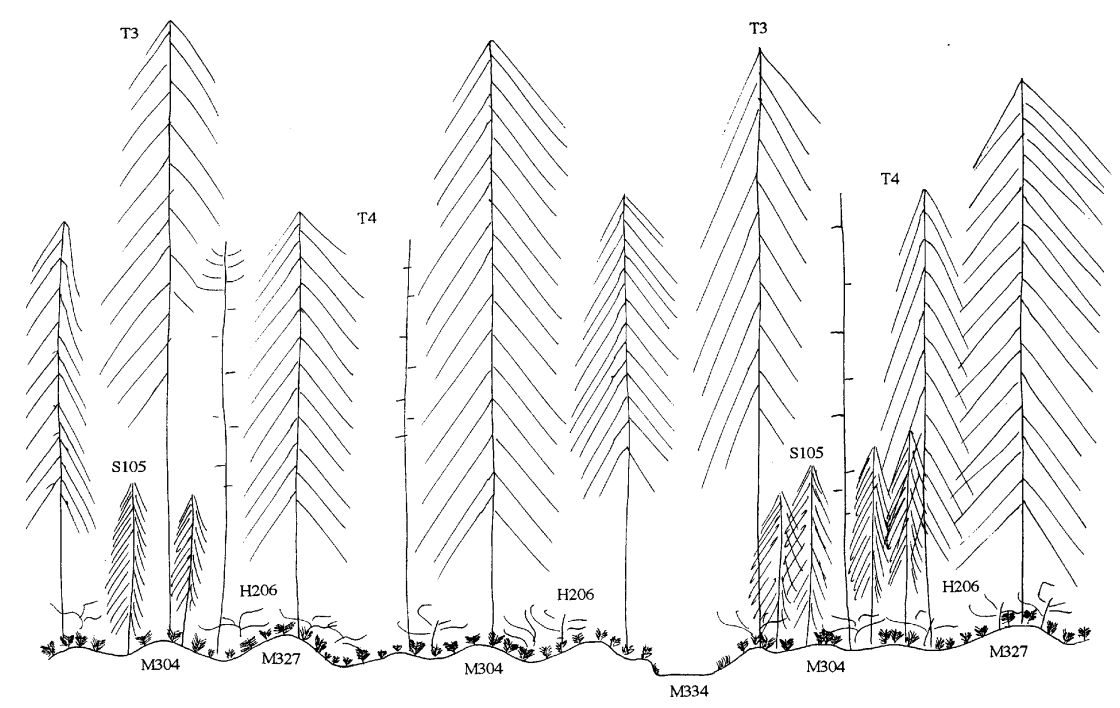

Figure 4. Sketch of the spatial pattern of the different synusiae in the bog pine and Norway spruce mixed stand of phytocoenosis No 2 . See also the dynamic diagram in Figure 5, the synusial relevés in Table I, and the short description of the elementary syntaxa in the appendix.

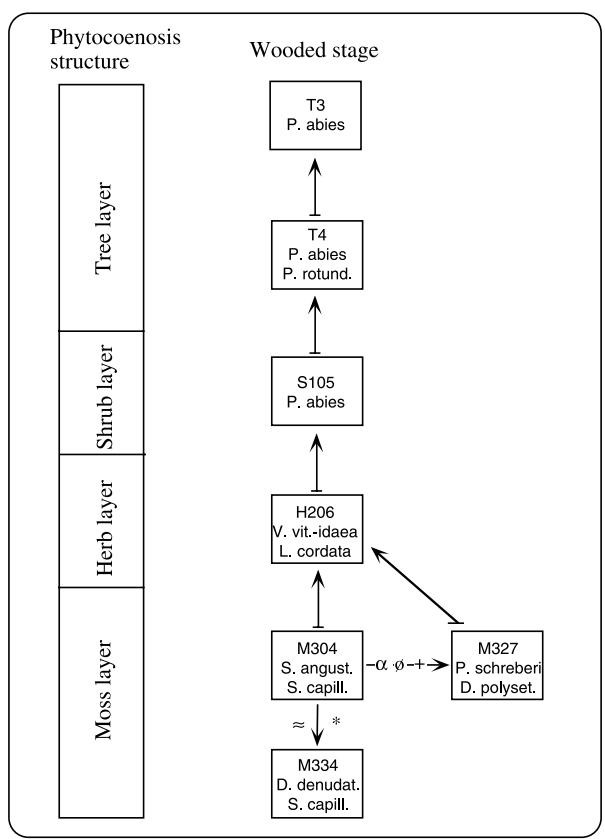

Figure 5. Diagram representing the spatial relationships, the hypothetical vegetation dynamics and ecological transformations between the synusiae in the bog pine and Norway spruce mixed stand of phytocoenosis No 2. For each synusia, elementary-syntaxon code is indicated together with the most characteristic species. All synusial relevés are reported in Table I and a short description is given in the appendix. The caption to spatial relationships, hypothetical vegetation dynamics and ecological transformations is indicated in Figure 3.

\subsection{Tree radial growth, colonization, and competition}

Norway spruces colonized the plot of Norway spruce and bog pine mixed stand since 1800 , while currently living bog pines settled more recently, after 1875 (Fig. 7b). Dominant and sub-dominant spruce radial growth increased similarly between 1875 and 1930, but later it clearly diverged (Fig. 7a).

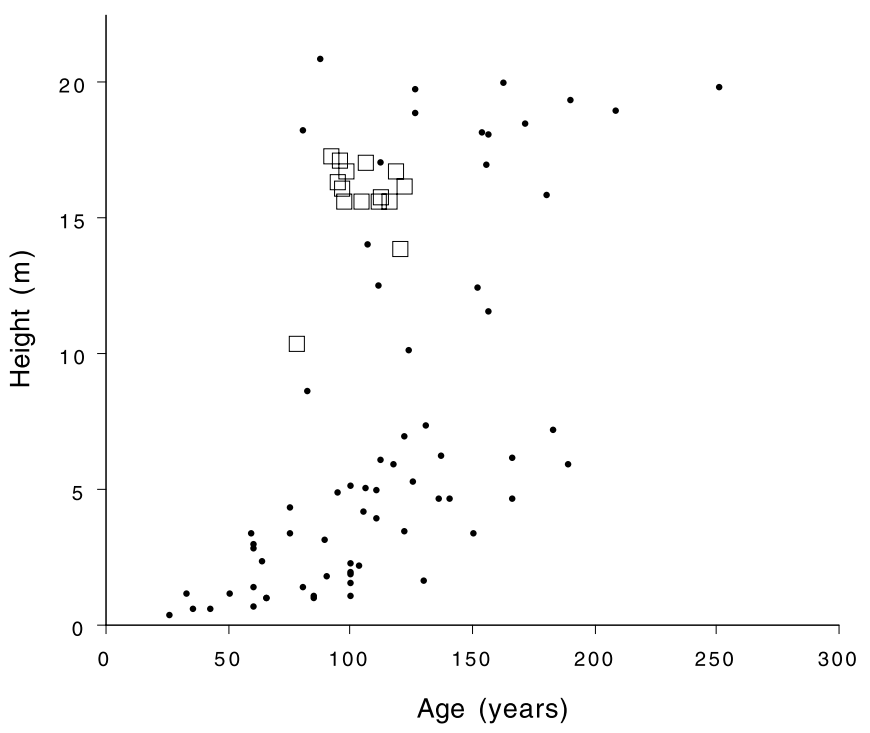

Figure 6. Relation between height and age of the living bog pines (open squares) and Norway spruces (black circles) in the bog pine and Norway spruce mixed stand of the phytocoenosis No 2 .

The dominant trees maintained a slow increase of radial growth whereas the radial growth of the sub-dominant ones decreased. Initial radial growth of pine trees was at its maximum between 1890 and 1930 (Fig. 7a), but then decreased abruptly until today, leading progressively to the actual death rate of the pine stand.

\section{DISCUSSION}

\subsection{Reconstruction of the past}

Past historical data [28, 14, 45], our comparative observations on the vegetation in both phytocoenoses of Les Saignolis bog as well as dendroecological investigations in the 
Table II. General characteristics of the bog pine and Norway spruce mixed stand in the phytocoenosis No 2. Mean and one standard deviation (in brackets) are given for the measured tree descriptors.

\begin{tabular}{|c|c|c|c|c|c|c|c|c|c|}
\hline \multirow[b]{2}{*}{ Species } & \multirow[b]{2}{*}{ Status } & \multicolumn{3}{|c|}{ Stand descriptors } & \multicolumn{5}{|c|}{ Tree descriptors } \\
\hline & & $\begin{array}{l}\text { Number } \\
\text { of trees }\end{array}$ & $\begin{array}{c}\text { Density } \\
\left(\text { trees } \text { ha }^{-1}\right)\end{array}$ & $\begin{array}{c}\text { Basal area } \\
\left(\mathrm{m}^{2} \mathrm{ha}^{-1}\right)\end{array}$ & $\begin{array}{l}\text { Maximum height } \\
(\mathrm{m})\end{array}$ & $\begin{array}{l}\text { Mean height } \\
\text { (m) }\end{array}$ & $\begin{array}{l}\text { Mean diameter } \\
(\mathrm{cm})\end{array}$ & $\begin{array}{l}\text { Mean age } \\
\text { (years) }\end{array}$ & $\begin{array}{l}\text { Mean annual apical growth } \\
\left(\mathrm{cm} \text { year }{ }^{-1}\right)\end{array}$ \\
\hline Bog pine & living & 15 & 375 & 32.42 & 17.3 & $15.8(1.7)$ & $32.8(5.3)$ & $104(12)$ & $14.5(2.0)$ \\
\hline Bog pine & dead & 11 & 275 & 12.98 & 12.9 & $9.2(1.9)$ & $24.1(4.4)$ & - & - \\
\hline Norway spruce & living & 69 & 1725 & 42.22 & 20.9 & $7.5(6.7)$ & $14.1(12.4)$ & $112(45)$ & $3.1(1.4) / 11.7(4.3) \ddagger$ \\
\hline Norway spruce & dead & 12 & 300 & 0.67 & 4.0 & $2.1(1.0)$ & $4.9(2.3)$ & - & - \\
\hline
\end{tabular}

$\ddagger$ For two height subgroups, $<8 \mathrm{~m}$ and $>8 \mathrm{~m}$ respectively.
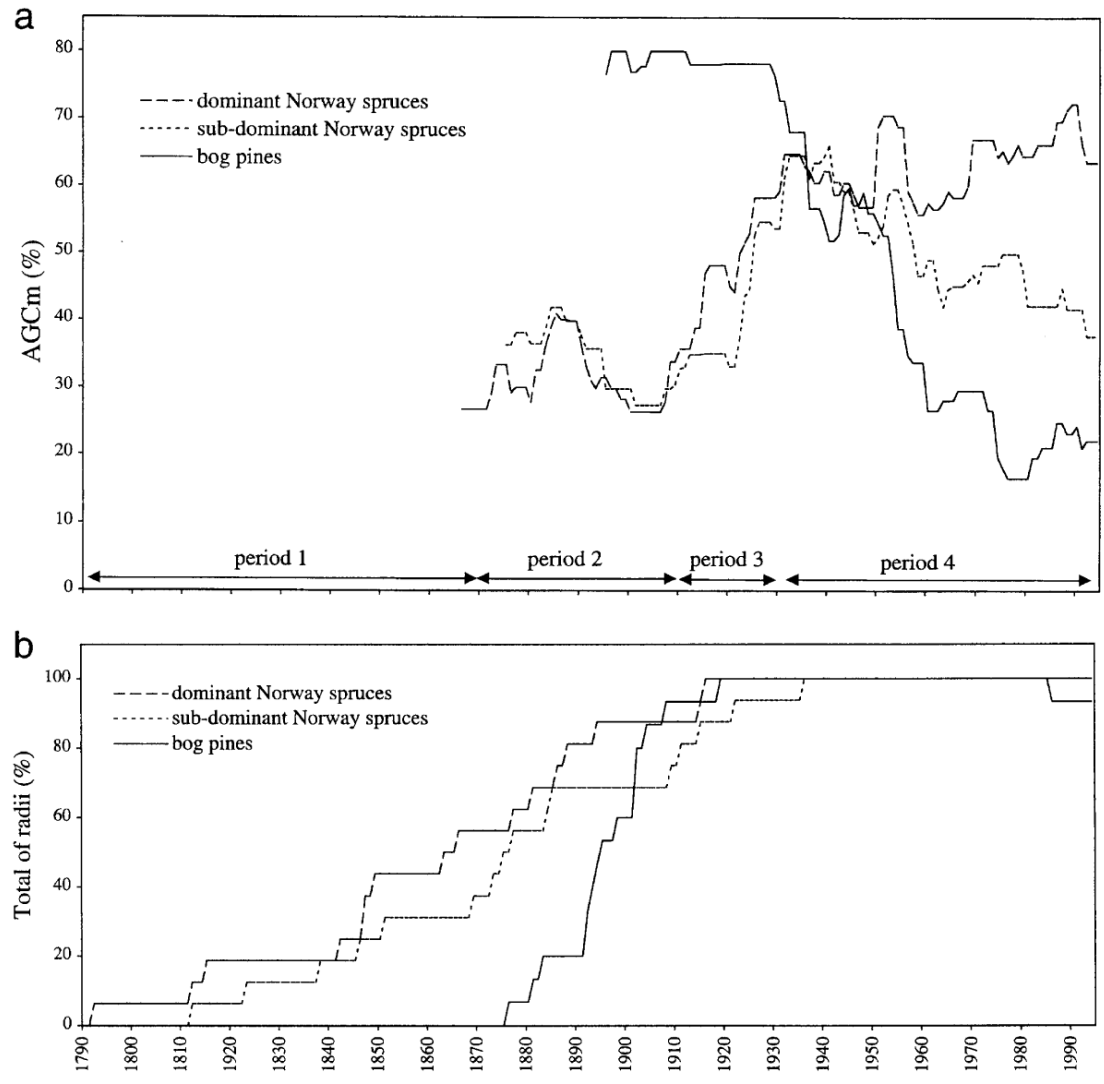

Figure 7. Abrupt growth change means (AGCm) curves (a) and corresponding curves for the total number of radii which have been read (b) for living trees of the canopy and the sub-canopy in the bog pine and Norway spruce mixed stand of phytocoenosis No 2. Dominant Norway spruces (height $>13 \mathrm{~m} ; n=16$ ), sub-dominant Norway spruces (height $<13 \mathrm{~m} ; n=16$ ), and bog pines ( $n=$ 15) are considered separately. AGCm curves are drawn only for the period at which more than half of the radii were represented in the corresponding years. Main events read in AGCm curves led to the distinction of several periods. mixed stand, and other large-scale vegetation surveys [16, 18] led us to propose a reconstruction of the recent past of Les Saignolis bog (Fig. 8). Lesquereux [28] reported that a major clearing took place on Les Saignolis bog near the end of the 18th century. Indeed, after 1790 (Fig. 7b: period 1), a first spruce cohort, today still alive, colonized the phytocoenosis No 2. According to Favre and Thiébaud [14], the spruce was not alone, and settled simultaneously with the bog pine and the pubescent birch (Fig. 1). Since no pine or birch of the first cohort were found during our work in phytocoenosis No 2, we suppose that these trees disappeared afterward. During the second period (1870-1910), the present pine cohort settled and grew rapidly as a result of the drainage ditches, which are still visible today. Suppressed by dominant pines, spruces showed a temporary growth reduction around 1900 (Fig. 7a). Between 1910 and 1930 (period 3), spruce showed a new increase of radial growth, while that of the bog pines was maximal and while in three other sites studied in the Jura bog pine showed a drastic growth reduction due to climatic factors near 1920 [17]. Overtopped by spruces, bog pines decreased their growth very quickly and many of their individuals began to die (period 4) while other bog pines in the Jura increased their growth near 1950 [17] but this latter trend is visible for dominant and subdominant spruces in Les Saignolis (Fig. 7a). Furthermore, since 1930 spruce growth curves diverge and point to an intra-specific competition in relation to the different light conditions between trees of canopy and subcanopy layers. 


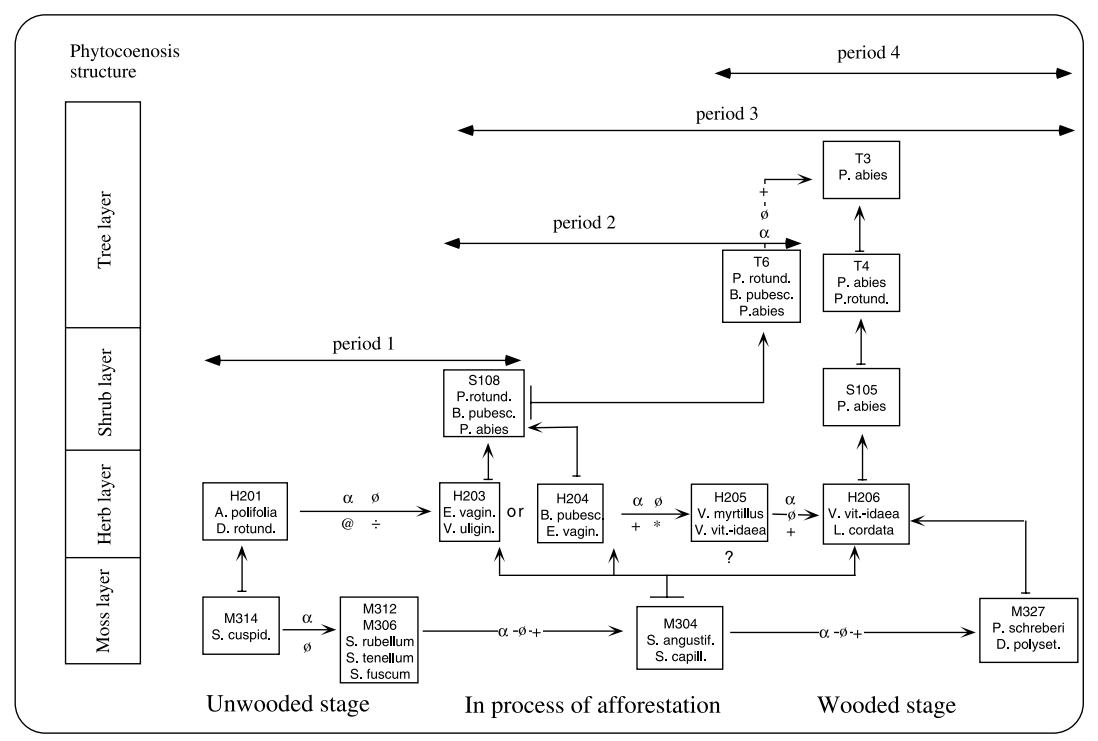

Figure 8. Generalized hypothetical qualitative dynamic model of the vegetation in the bog pine and Norway spruce mixed stand of phytocoenosis No 2. The diagram was drawn using the elementary syntaxa occurring in phytocoenoses No 1 and No 2 (see Figs. 3 and 5) and is completed with others resulting from the whole typology of the original work [16]. For each synusia, elementary-syntaxon code is indicated (e.g. H201) together with the most characteristic species. Short descriptions of elementary syntaxa are given in the appendix. The caption to spatial relationships, hypothetical vegetation dynamics and ecological transformations between the synusiae in relation to tree colonization is given in Figure 3. Periods are the same as in Figure 7.

The vegetation succession results of both autogenic (i.e., intrinsic vegetation dynamics) and allogenic processes (e.g. climate change or anthropic disturbances), but the respective importance of each cause is not easy to evaluate. In Les Saignolis bog, allogenic processes were predominant during the hole period but particularly following the clear cut and the drainage (period 1 to period 3 ) but it seems clear that autogenic processes, as drying up by pine or interspecific competition, increased during the recent past (period 3 and period 4).

\subsection{Survival potential of Norway spruce and bog pine}

In bog histosoils and in other hydromorphic soils, water level, soil aeration and transport ability of oxygen in roots are the main key-factors for tree survival and growth $[4,5,10,11$, $27,29,30,33,34,40,41]$ in relation with nutrient and water supplies [31, 32]. Schmid et al. [47] showed that eutrophication can promote spruce development in a bog pine stand. Drobyshev [13] pointed out that the spruce was the most frequent species in small gaps of Sphagnum old-growth forests, although less important in larger gaps, where other species could also settle, such as Sorbus aucuparia, Betula pubescens, Salix caprea, Populus tremula and Acer platanoides. In our study, we hypothesize that the clear cut acted as a large gap and promoted both light-demanding species Pinus uncinata var. rotundata and Betula pubescens, beside Picea abies. Even-aged tree populations reflect some disturbances [3, 25, 35]. In Jura bogs, even-aged stands of bog pine developing on deep and oligotrophic peat reflect mainly drainage and peat cuttings [17]. The pine population of the bog pine-spruce mixed stand in Les Saignolis reflects the temporary progres- sion of these trees into the spruce woodland. After Mitchell et al. [37], forest clearance around raised bogs isolated in karst environment may increase evapotranspiration, causing a lowering of the water table on the bog and a modification of the vegetation cover, and in particular bog pine encroachement. The forest clearance reported by Lesquereux [28] on the top of the anticlinal of Les Saignolis was not restricted to the bog and therefore the mesoclimate could have been affected according to Mitchell's hypothesis, generating the observed forest dynamics.

While mean apical growth of bog pine ranged between 1.8 and $10.8 \mathrm{~cm} \mathrm{yr}^{-1}$ in various situations on deep peat [17], it was higher in Les Saignolis $\left(14.5 \mathrm{~cm} \mathrm{yr}^{-1}\right)$, showing temporarily very favourable growth conditions. Despite the sharp transition which is mainly observed between spruce and bog pine stands in intact bogs of the Jura [16], our study shows that disturbances due to human activities may engender a displacement of the ecotone towards the centre of the bog, with development of spruces on the expanse of pines. Furthermore, we supposed that this ecotone was a probable primeval niche of bog pine in intact bogs [16]. Therefore, the same disturbances may have led ultimately to the centripetal progression of new bog pine cohorts of taller size in raised bogs of the Jura [17, 18].

Bog-pine's ecological strategy depends on the habitat. This species shows an r-strategy [36] in dry and minerotrophic habitats such as in tall pine woodlands [17] or in spruce forests (this issue). It settles and grows rapidly after disturbances in well lit and competitor free conditions. Trees grow quickly but have a short life span. On the contrary, in extreme wet and nutrient poor conditions such as in the central part of the bogs, this species shows a K-strategy. The settlement is slow, 
progressive, and the life span is longer, reaching 275 years [17]. Following the C-S-R strategies of Grime [22, 23, 39], bog pine shows both an $\mathrm{R}$ (ruderal) strategy in the first environment and an $\mathrm{S}$ (stress tolerant) one in the second. Among the succession mechanisms suggested by Connel and Slatyer [8], facilitation acts in the succession from bog pine to Norway spruce. The pioneers, pubescent birch and bog pine, which appear after a disturbance, could dry up the bog and so promote spruce settlement if nutrients are sufficient.

To conclude, it is interesting to note that the three tree species have settled simultaneously, two mostly known as pioneers (pubescent birch and bog pine) whereas the third (Norway spruce) is usually known as a late successional one. Noteworthy, the current pine population has settled several decades after the beginning of the secondary succession in an open stand of pre-established spruces probably suppressed by the shallow water level. The pioneer strategy of the bog pine was confirmed since their development was faster than that of the spruce. Finally, this latter species has eliminated the birch and the pine successively. The strategy of each single species is still to consider in relation to abiotic factors, in particular the nutrient status and the depth to water table, which are of great importance in raised bogs.

Beside diachronic (successive vegetation maps) and synchronic (synusial and phytocoenosis relevés) vegetation analysis and historical data, dendroecology has proved to be a very useful tool for reconstructing the past of Les Saignolis and to highlight the ecological processes at both levels of tree populations and of the ecosystem.

\section{APPENDIX}

Short description of the different syntaxa to whom relevés (see Figs. 2 to 5 and Tab. I) of the phytocoenoses No 1 and No 2 belong. After Freléchoux [16] and Freléchoux et al. [18].

T3. Monospecific tree layer syntaxon with Picea abies. Synusiae occur on the marginal belt of raised bogs, on shallow histosols, and Norway spruce forms dense stands.

T4. Tree layer syntaxon with Picea abies and Pinus uncinata var. rotundata. Synusiae occur at the contact zone between the marginal Norway spruce belt and the tall bog pine forest.

T6. Tree layer syntaxon with Pinus uncinata var. rotundata, Betula pubescens and Sorbus aucuparia. Picea abies is missing. Synusiae occur mainly in closed, tall pine forests.

S105. Shrub layer syntaxon with Picea abies which is constant and dominant. Synusiae occur on the marginal spruce belt forests.

S108. Shrub layer syntaxon with Picea abies, Betula pubescens and Sorbus aucuparia. Synusiae occur mainly in spruce forests.

H201. Herb layer syntaxon with Drosera rotundifolia, Carex pauciflora, Andromeda polifolia, Eriophorum vaginatum, Vaccinium oxycoccos, Pinus uncinata var. rotundata, Scirpus cespitosus and Calluna vulgaris. Synusiae occur on wet lawns at the edges of the hollows.
H203. Herb layer syntaxon with Vaccinium uliginosum, Calluna vulgaris, Eriophorum vaginatum, Vaccinium oxycoccos, Andromeda polifolia and Vaccinium myrtillus. Synusiae occur on drier lawns and hummocks.

H205. Herb layer syntaxon with Vaccinum myrtillus, V. vitis-idaea and V. uliginosum. Synusiae occur on drier and more shaded hummocks in pine, birch and spruce forests.

H206. Herb layer syntaxon with Vaccinium vitis-idaea, Listera cordata and Vaccinium myrtillus. Synusiae occur in very shaded locations, mainly in spruce forests. It also occurs in tall pine stands, in the understorey of the dense V. myrtilluslayer.

M304. Moss layer syntaxon with Sphagnum capillifolium, S. magellanicum, S. angustifolium and Polytrichum strictum. Synusiae occur in shady and dry locations in pine, birch and spruce forests, mainly under a Vaccinium-layer.

M306. Moss layer syntaxon with Sphagnum rubellum, S. magellanicum, Polytrichum strictum, Aulacomnium palustre, Sphagnum angustifolium and S. fuscum. Synusiae occur in open and wet locations, on wet lawns at the border of oligotrophic hollows of the middle of raised bogs.

M312. Moss layer syntaxon with Sphagnum rubellum, S. tenellum, S. magellanicum, S. papillosum and S. cuspidatum. Synusiae occur on the wettest part of the oligotrophic hollows.

M327. Moss layer syntaxon with Pleurozium schreberi, Hylocomium splendens, Dicranum polysetum and Ptilium crista-castrensis. Synusiae occur under the dryest and shadiest locations, only in tall pine forests.

M334. Moss layer syntaxon with Dicranodontium denudatum, Sphagnum capillifolium, S. magellanicum and Mylia anomala. Synusiae occur in wet shady locations on bare peat.

Acknowledgements: The authors are grateful to the anonymous reviewers for valuable comments on the manuscript and to B. Corboz and A. Robinson for translation supervision. This research forms part of the Ph.D. thesis of F.F. and was funded by the Swiss National Science Foundation (Grant No 31-34047.92).

\section{REFERENCES}

[1] Annales de 1'Institut météorologique suisse, 1931-2002.

[2] Bartolomé B., Étude pédologique et phytosociologique de la tourbière des Saignolis, Travail de diplôme, Laboratoire d'écologie et de phytosociologie, Institut de botanique, Université de Neuchâtel, 1990.

[3] Bergeron Y., Gagnon D., Age structure of red pine (Pinus resinosa Ait.) at its northern limit in Quebec, Can. J. For. Res. 17 (1987) 129-137.

[4] Boggie R., Response of seedlings of Pinus contorta and Picea sitchensis to oxygen concentrations in culture solution, New Phytol. 73 (1974) 467-473.

[5] Boggie R., Water-table depth and oxygen content of deep peat in relation to root growth of Pinus contorta, Plant Soil 48 (1977) $447-$ 454.

[6] Buttler A., Cornali Ph., Richard J.-L., La tourbière des Pontins sur St-Imier, Mater. Leve Geobot. Suisse 59 (1983) 1-79.

[7] Braun-Blanquet J., Pflanzensoziologie, Grundzüge der Vegetationskunde, ed. 3, Springer Verlag, Wien, 1964. 
[8] Connell J., Slatyer R., Mechanism of succession in natural communities and their role in community stability and organization, Am. Nat. 111 (1977) 1119-1144.

[9] Corley M.F.V., Crundwell A.C., Düll R., Hill O., Smith A.J.E., Mosses of Europe and the Azores: An annotated list of species, with synonyms from the recent literature, J. Bryol. 11 (1981) 609-689.

[10] Coutts M.P., Philipson J.J., The tolerance of tree roots to waterlogging. I. Survival of Sitka spruce and Lodgepole pine, New Phytol. 80 (1978) 63-69.

[11] Coutts M.P., Philipson J.J., The tolerance of tree roots to waterlogging. II. Adaptation of Sitka spruce and Lodgepole pine to waterlogged soil, New Phytol. 80 (1978) 71-77.

[12] Douglass A.E., Crossdating in Dendrochronology, J. For. 39 (1939) $825-831$.

[13] Drobyshev I.V., Regeneration of Norway spruce in canopy gaps in Sphagnum-Myrtillus old-growth forests, For. Ecol. Manag. 115 (1999) 71-83.

[14] Favre J., Thiébaud M., Monographie du Marais de Pouillerel, Bull. Soc. Neuchatel. Sci. Nat. 34 (1907) 25-87.

[15] Feldmeyer-Christe E., Étude phytoécologique des tourbières des Franches-Montagnes (cantons du Jura et de Berne, Suisse), Mater. Leve Geobot. Suisse 66 (1990) 1-163.

[16] Freléchoux F., Étude du boisement des tourbières hautes de la chaîne jurassienne: typologie et dynamique de la végétation approche dendroécologique des peuplements arborescents, Ph.D. thesis, Université de Neuchâtel, 1997.

[17] Freléchoux F., Buttler A., Schweingruber F.H., Gobat J.-M., Stand structure, invasion, and growth dynamics of bog pine (Pinus uncinata var. rotundata) in relation to peat cutting and drainage in the Jura Mountains, Switzerland, Can. J. For. Res. 30 (2000) 1114 1126.

[18] Freléchoux F., Buttler A., Gillet F., Dynamics of bog-pinedominated mires in the Jura Mountains, Switzerland: A tentative scheme based on synusial phytosociology, Folia Geobot. 35 (2000) 273-288.

[19] Gallandat J.-D., Gillet F., Havlicek E., Perrenoud A., Typologie et systémique phytoécologiques des pâturages boisés du Jura suisse, Laboratoire d'écologie végétale, Université de Neuchâtel, rapport final de mandat Offices fédéraux et cantonaux, 1995.

[20] Gillet F., De Foucault B., Julve P., La phytosociologie synusiale intégrée: objets et concepts, Candollea 46 (1991) 315-340.

[21] Gillet F., Gallandat J.D., Integrated synusial phytosociology: some notes on a new multiscalar approach to vegetation analysis, J. Veg. Sci. 7 (1996) 13-18.

[22] Grime J.P., Vegetation classification by reference to strategies, Nature 250 (1974) 26-31.

[23] Grime J.P., Plant strategies and vegetation processes, Wiley, Chichester, 1979.

[24] Grolle R., Hepatics of Europe including the Azores: An annotated list of species, with synonyms from the recent literature, J. Bryol. 12 (1983) 403-459.

[25] Groot A., Horton B.J., Age and size structure of natural and secondgrowth peatland Picea mariana stands, Can. J. For. Res. 24 (1994) 225-233.

[26] Guinochet M., Carte des groupements végétaux de la France, Pontarlier 5-6, 1/20.000, CNRS, Paris, 1955.

[27] Lees J.C., Soil aeration and Sitka spruce seedling growth in peat, J. Ecol. 60 (1973) 343-349.

[28] Lesquereux L., Quelques recherches sur les marais tourbeux en général, Ed. Henry Wolfrath, Neuchâtel, 1844.

[29] Lévy G., Influence sur l'engorgement de printemps et de la sécheresse d'été sur le comportement de jeunes plants d'épicéa, Ann. Sci. Forest. 28 (1971) 403-423.

[30] Lévy G., Premiers résultats concernant deux expériences d'assainissement du sol sur plantations de résineux, Ann. Sci. Forest. 29 (1972) 427-450.
[31] Lévy G., Nutrition et production de l'épicéa commun adulte sur sols hydromorphes en Lorraine: liaisons avec les caractéristiques stationnelles, Ann. Sci. Forest. (1978) 33-53.

[32] Lévy G., La nutrition azotée de l'épicéa sur sol engorgé : étude expérimentale, Ann. Sci. Forest. 38 (1981) 163-178.

[33] Lieffers V.J., Rothwell R.L., Effects of depth of water table and substrate temperature on root and top growth of Picea mariana and Larix laricina seedlings, Can. J. For. Res. 16 (1986) 1201-1206.

[34] Lieffers V.J., Rothwell R.L., Rooting of peatland black spruce and tamarack in relation to depth of water table, Can. J. Bot. 65 (1987) $817-821$.

[35] Lorimer C.G., Methodological considerations in the analysis of forest disturbance history, Can. J. For. Res. 15 (1985) 200-213.

[36] MacArthur R.H., Wilson E.O., The theory of island biogeography, Princeton Univ. Press, Princeton, 1967.

[37] Mitchell E.A.D., van Der Knaap W.O., van Leeuven J.F.N., Buttler A., Warner B.G., Gobat J.-M., The palaeoecological history of the Praz-Rodet bog (Swiss Jura) based on pollen, plant macrofossils and testate Amoebae (Protozoa), The Holocene 11 (2001) 65-80.

[38] Oberdorfer E., Pflanzensoziologische Excursions Flora, Ulmer, Stuttgart, 1990.

[39] Packham J.R., Harding D.J.L., Hilton G.M., Stuttard R.A., Functional Ecology of Woodlands and Forest, Chapman \& Hall, London, 1992.

[40] Philipson J.J., Coutts M.P., The tolerance of tree roots to waterlogging. III. Oxygene transport in Lodgepole pine and Sitka spruce roots of primery structure, New Phytol. 80 (1978) 341-349.

[41] Philipson J.J., Coutts M.P., The tolerance of tree roots to waterlogging. IV. Oxygene transport in woody roots of sitka spruce and lodgepole pine, New Phytol. 85 (1980) 489-494.

[42] Rameau J.-C., Contribution phytoécologique et dynamique à l'étude des écosystèmes forestiers - Applications aux forêts du Nord-Est de la France, Thèse, Université de Besançon, No 218, 1987.

[43] Richardson D.M., Bond W.J., Determinant of plant distribution: Evidence from pine invasions, Am. Nat. 137 (1991) 639-668.

[44] Richard J.-L., Les forêts acidophiles du Jura, Mater. Leve Geobot. Suisse 38 (1961) 1-164.

[45] Richard J.-L., Extraits de la carte phytosociologique des forêts du Canton de Neuchâtel, Mater. Leve Geobot. Suisse 57 (1965) 1-48.

[46] Sandoz H., Recherches taxonomiques, biogéographiques et phytoécologiques sur les principaux conifères subalpins des Alpes: Mélèze d'Europe, pin cembro, pin à crochets et pin mugho, Thèse, Université d'Aix-Marseille III, 1987.

[47] Schmid J., Bogenrieder A., Schweingruber F.H., Verjüngung und Wachstum von Moor-Kiefer (Pinus rotundata Link) und Fichten (Picea abies [L.] H. Karsten) in Mooren des Südöstlichen Schwarzwaldes (Süddeutschland), Mitt. Eidgenöss, Forsch. Anst. Wald Schnee Landsch. 70 (1995) 175-223.

[48] Schweingruber F.H., Eckstein D., Serre-Bachet F., Bräcker O.U., Indentification, presentation and interpretation of event years and pointer years in dendrochronology, Dendrochronologia 8 (1990) 9-38.

[49] Stokes M., Smiley T.L., An introduction to tree-ring dating, University Press, Chicago, 1968

[50] Tutin T.G., Heywood V.H., Burges N.A., Valentine D.H., Walters S.M., Webb D.A. (Eds.), Flora europaea, 1-5, Cambridge University Press, Cambridge, 1964-1980.

[51] Weber U.M., Computer-aided processing and graphical presentation of skeleton plots using commercial software packages, Dendrochronologia 12 (1994) 147-158.

[52] Weber U.M., Schweingruber F.H., A dendroecological reconstruction of western spruce budworm outbreaks (Choristoneura occidentalis) in the Front Range, Colorado, from 1720 to 1986, Trees 9 (1995) 204-213. 